\title{
The Ebola Virus Disease Outbreak and the Mineral Sectors of Guinea, Liberia, and Sierra Leone
}

On March 23, 2014, the World Health Organization (WHO) made the first announcement of what would become the largest Ebola virus disease (EVD) outbreak since the discovery of the disease in West Africa in 1976. At the forefront of world news regarding the deadly virus were Guinea, Liberia, and Sierra Leone, the three countries most affected by the EVD outbreak (World Health Organization, 2014). Projected economic growth for these three countries in 2014 and 2015 had hinged on the expected development of their respective mineral sectors, which play a significant role in the economy of all three countries in terms of the contribution to the gross domestic product (GDP) and to export revenues. The mineral sector, in particular the iron ore industry, has played a significant role in the economic growth experienced by Liberia and Sierra Leone in recent years. Uncertainty regarding the status of mining and mineral exploration operations in the three countries following the onset of the EVD outbreak and changes in mineral market conditions raised questions regarding the prospects for such growth and future foreign direct investment in the region (World Bank Group, 2014). Figure 1 shows the total number of reported EVD cases as of yearend 2014, and the geographic location of active mining operations and mineral facilities in Guinea, Liberia, and Sierra Leone.

This fact sheet provides data and information about (1) the mineral sectors of Guinea, Liberia, and Sierra Leone and the importance of the sector to the economy of each country; (2) the distribution of mines and mineral facilities, projects in development, and reported EVD cases; and (3) potential risks of the outbreak to investment in and development of new mines, processing facilities, and related mineral industry infrastructure.

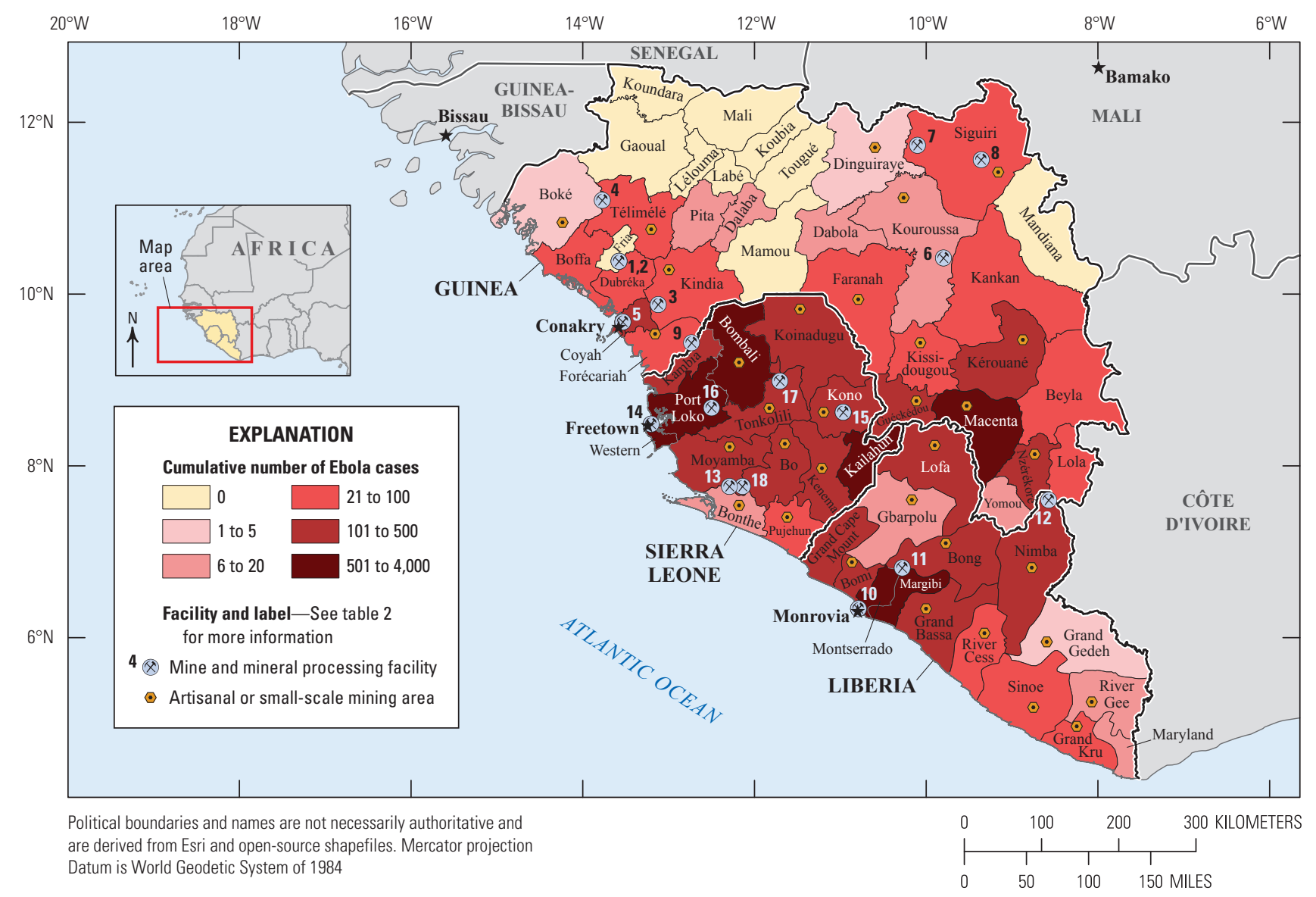

Figure 1. Active mining operations and mineral processing facilities in Guinea, Liberia, and Sierra Leone and reported cases of Ebola as of yearend 2014. Numbered facility labels correspond to entries in table 2. District-level Ebola virus disease data derived from World Health Organization $(2014,2015)$ data as of December 2014. 


\section{Background}

Guinea, Liberia, and Sierra Leone's shared histories of civil unrest and related economic disruptions have served as deterrents to the development of the mineral sector in each of these countries. Coups d'état and prolonged periods of civil war heavily damaged infrastructure including government buildings, roads, bridges, ports, and railways, which are central to the development of the mineral sector. Since 2011, progress has been made in the rehabilitation of infrastructure in all three countries; however, much of it is still in need of repair. Poor infrastructure and inadequate electric power continue to be a major deterrent to foreign direct investment in mining (Pushak and Foster, 2011, p. 1-10; World Bank, 2013, p. 1-5; 2014).

Table 1 shows Guinea's, Liberia's, and Sierra Leone's mineral production by commodity and each country's mineral sector contribution to GDP and export earnings in 2012. Guinea was among the world's leading producers of bauxite in 2012, accounting for about 6 percent of world bauxite output. The country was also a significant world producer of rough diamond. Production of bauxite was from the Friguia, Debele, and Sangaredi Mines (table 2, nos. 2-4).

Liberia produces cement, rough diamond, small amounts of gold, and iron ore. For many years, Liberia's economy had relied heavily on production and exports of iron ore, which came to a halt in 1990 following the onset of civil war in Liberia. Diamond proceeds were used to a large extent to finance the civil war, which resulted in the United Nations Security Council imposing roughdiamond export sanctions on Liberia in 2001. Diamond sanctions were eventually lifted in April 2007 and production of iron ore resumed in 2011 (United Nations Security Council, 2007, p. 3, 7-8).

Sierra Leone produces cement, rough diamond, small amounts of gold, iron ore, and mineral sands (ilmenite and rutile). Bauxite and mineral sands production came to a standstill in 1994 owing to civil war in Sierra Leone. Because diamonds were also used to finance the civil war, diamond export sanctions were also imposed on the country. The civil war ended in 2002 and diamond sanctions were lifted in 2003. Production of bauxite from the Sierra Minerals Mine (table 2, no. 13) and mineral sands from the Sierra Rutile Mine (table 2, no. 18) resumed in 2006. Sierra Leone began producing iron ore again in 2011 with the reopening of the Marampa Mine (table 2, no. 16) and the opening of the Tonkolili Mine (table 2, no. 17). Sierra Leone's production of rutile (94,493 metric tons [t]) accounted for more than 11 percent of world rutile output in 2012.

Figure 2 shows the mineral sector share of GDP for Guinea, Liberia, and Sierra Leone. Guinea's mineral sector share of GDP fluctuated between 14 and 15 percent from 2004 to 2011 (fig. 2). The sector accounted for about 14 percent of the country's GDP in 2012 and for about 90 percent of export earnings. Guinea's sector share of GDP was estimated to have decreased to 12.5 percent in 2013 owing partly to a decrease in the production of alumina caused by the temporary closure of the country's alumina plant as a result of a trade union strike.

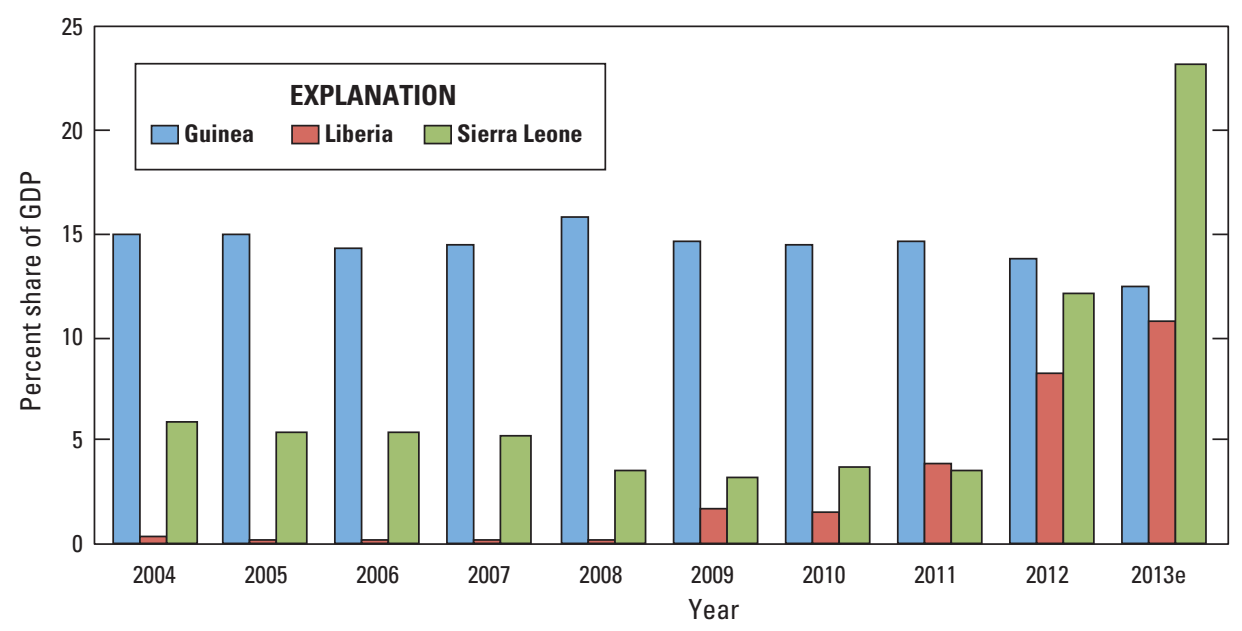

Figure 2. Mineral sector share of gross domestic product (GDP). Sources of data include the Central Bank of Liberia (2015), Bank of Sierra Leone (2015), Guinea Institut National de la Statistique (2014), and International Monetary Fund (2014). e, estimated.

Table 1. Mineral production and mineral sector contribution to gross domestic product (GDP) in 2012.

[Mineral production reported in thousands of metric tons unless otherwise specified. Abbreviations used: kg, kilogram; t, metric ton; NA, not applicable]

\begin{tabular}{|c|c|c|c|c|c|c|c|c|c|}
\hline Location & Alumina & Bauxite & Cement & $\begin{array}{l}\text { Diamond } \\
\text { (carats) }\end{array}$ & $\begin{array}{l}\text { Gold } \\
\text { (kg) }\end{array}$ & $\begin{array}{l}\text { Iron ore } \\
\text { (metal } \\
\text { content) }\end{array}$ & $\begin{array}{l}\text { Mineral sands } \\
\text { (ilmenite } \\
\text { and rutile) } \\
\text { (t) }\end{array}$ & $\begin{array}{l}\text { Percentage } \\
\text { mineral sector } \\
\text { contribution } \\
\text { to GDP }\end{array}$ & $\begin{array}{c}\text { Percentage } \\
\text { of export } \\
\text { earnings }\end{array}$ \\
\hline World & ${ }^{1} 97,000$ & ${ }^{1} 259,000$ & ${ }^{2} 3,830,000$ & ${ }^{3} 128,000,000$ & ${ }^{4} 2,710,000$ & ${ }^{5} 1,390,000$ & ${ }^{6} 8,610,000$ & NA & NA \\
\hline Guinea $^{7}$ & 150 & 16,041 & 317 & ${ }^{3} 266,800$ & 14,790 & Not disclosed & NA & ${ }^{8,9} 14$ & 8,990 \\
\hline Liberia $^{10}$ & NA & NA & 122 & ${ }^{3} 41,985$ & 641 & 1,980 & NA & ${ }^{11} 8$ & ${ }^{11} 35$ \\
\hline Sierra Leone ${ }^{12}$ & NA & 776 & 335 & ${ }^{3} 541,166$ & ${ }^{13} 145$ & 3,600 & 117,083 & ${ }^{14} 12$ & ${ }^{14} 70$ \\
\hline \multicolumn{3}{|c|}{$\begin{array}{l}{ }^{1} \text { E. Lee Bray, U.S. Geological Survey, } \\
\text { unpub. data. } \\
{ }^{2} \text { van Oss, } 2015 . \\
{ }^{3} \text { Kimberley Process Rough Diamond } \\
\text { Statistics, } 2013 .\end{array}$} & \multicolumn{2}{|c|}{$\begin{array}{l}{ }^{4} \text { Micheal W. George, U.S. } \\
\text { Survey, unpub. data. } \\
{ }^{5} \text { Tuck, 2014. } \\
{ }^{6} \text { Bedinger, 2014. } \\
{ }^{7} \text { Bermúdez-Lugo, 2014a. }\end{array}$} & ogical & \multicolumn{2}{|c|}{$\begin{array}{l}{ }^{8} \text { Guinea Institut National } \\
\text { de la Statistique, } 2014 . \\
{ }^{9} \text { International Monetary } \\
\text { Fund, 2014. } \\
{ }^{10} \text { Bermúdez-Lugo, 2014b. }\end{array}$} & \multicolumn{2}{|c|}{$\begin{array}{l}{ }^{11} \text { Central Bank of Liberia. } \\
{ }^{12} \text { Bermúdez-Lugo, 2014c. } \\
{ }^{13} \text { Omayra Bermúdez-Lugo, U.S. } \\
\text { Geological Survey, unpub. data. } \\
{ }^{14} \text { Bank of Sierra Leone, } 2014 .\end{array}$} \\
\hline
\end{tabular}


In Liberia, prior to 1990 , the contribution of the mineral sector to GDP stood at an average of about 25 percent, mostly driven by diamond and iron ore production. The contribution of Liberia's mineral sector to GDP began to increase in 2007 as the embargo on diamond exports was lifted. Figure 2 shows the increase in the share of GDP accounted for by minerals, which was about 8 percent in 2012 .

Sierra Leone's mineral sector accounted for about 12 percent of GDP in 2012 and for about 70 percent of export earnings. Prior to the civil war, the sector's share of GDP averaged about 15 percent, mostly driven by the production of bauxite, cement, diamond, and mineral sands. For 2013, the estimated contribution of the mineral sector to GDP in Guinea, Liberia, and Sierra Leone was about 13, 11, and 23 percent, respectively.

\section{The Ebola Virus Disease Outbreak Crisis}

The first laboratory-confirmed case of the EVD was reported by the Ministry of Health in Guinea on March 21, 2014. By early June, wide transmission of the EVD was confirmed in Liberia and Sierra Leone. The number of EVD cases peaked in late October and early November and by yearend had affected more than 20,000 people. As of January 18, 2015, the rate of infection had decreased significantly; however, transmission of the EVD continued in all three countries, with the total number of cumulative cases reported to be 21,797 (fig. 3) (Centers for Disease Control and Prevention, 2015a,b).

\section{Changing Mineral Market Conditions in 2014}

Coincidentally, the emergence of the EVD crisis was accompanied by changes in market conditions, which were likely to affect Government revenues from the mineral sector, as iron ore was expected to become an increasingly significant source of future export earnings for all three countries and bauxite accounts for the majority of Guinea's export earnings. These changes in market conditions included (1) a decrease in aluminum and bauxite prices following the recession of 2009, which affected world consumption of bauxite; combined with (2) a ban

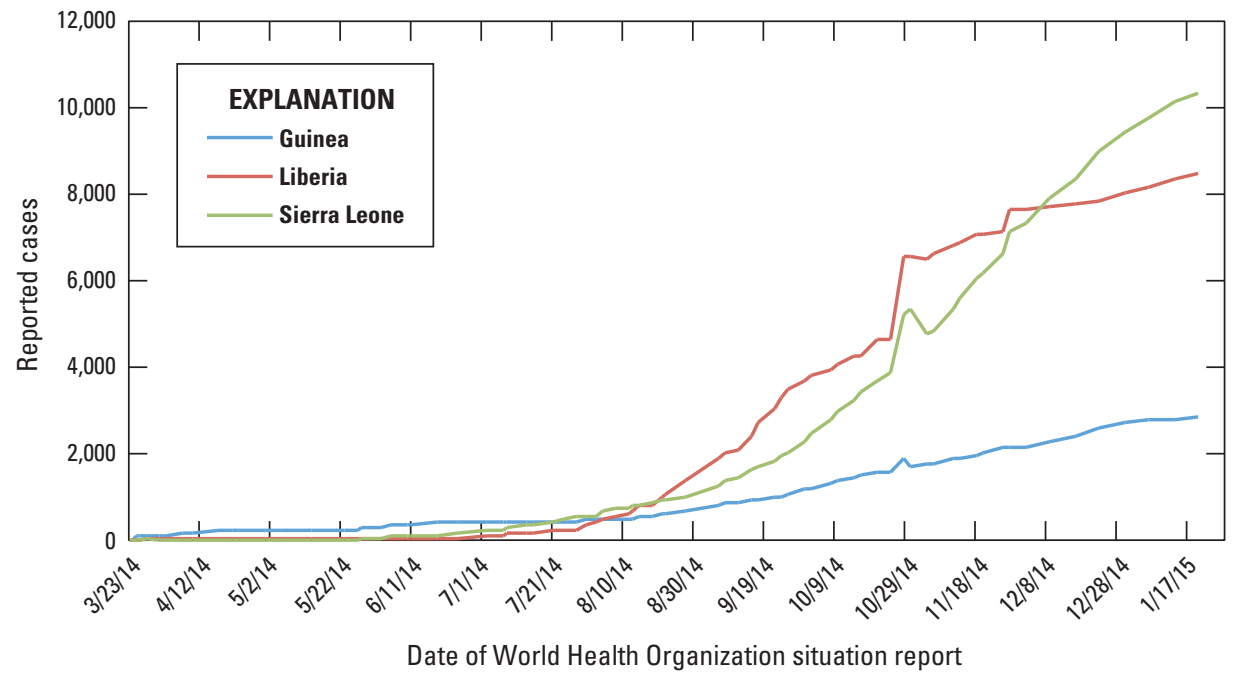

Figure 3. Cumulative reported cases of the Ebola virus disease as of January 18, 2015 (Centers for Disease Control and Prevention, 2015b). Data reported by the Centers for Disease Control are based on World Health Organization (WHO) situation reports and correspond to the total number of reported suspected, probable, and confirmed cases of the Ebola virus disease for the period of March 23, 2014, to January 18, 2015.

imposed by Indonesia-one of the leading sources of global exports of bauxite - on the export of unprocessed minerals including bauxite; and (3) a decrease in the global price of iron ore from $\$ 130$ per metric ton in early 2014 to $\$ 68$ per metric ton at yearend (Gleeson, 2014).

\section{Operating Status of Mines and Mineral Facilities}

The names and locations of existing mining operations in Guinea, Liberia, and Sierra Leone and the names of major equity owners are listed in table 2 . Most of the mining companies operating in these three countries reported that mining had continued mostly uninterrupted in 2014. Several mines were placed on care-and-maintenance status for reasons other than the EVD outbreak.

In Guinea, mining operations that continued mostly uninterrupted during 2014 included that of the Debele and Sangaredi bauxite mines (table 2, nos. 3, and 4); the Kiniero, Lefa, and Siguiri gold mines (table 2, nos. 6, 7, and 8); and the Ciments de Guinée cement plant (table 2, no. 5). In Liberia, mining operations continued at the Bong and Western Range Project iron ore mines (table 2, nos. 11 and 12) and the Cemenco cement plant (table 2, no. 10). In Sierra Leone, the Sierra Minerals bauxite mine (table 2, no. 13) was active as of June 30. Mining companies reported anticipating a reduction in bauxite production owing to operational issues resulting not only from the EVD outbreak, but also from adverse weather conditions and social tensions in the country. The Sierra Rutile mineral sands mine (table 2, no. 18) continued to operate throughout the year although annual production was lower than expected, largely owing to challenges presented by the EVD outbreak (Sierra Rutile Ltd., 2015). Two workers from the Koidu Kimberlite Mine (table 2, no. 15), in the Kono District, contracted the EVD in early December. Two significant mine closures in Sierra Leone occurred during the year: that of the Marampa iron ore mine (table 2, no. 16) and the Tonkolili Mine (table 2, no. 17). The closure of these mines was related to the decrease in global iron ore prices and to issues related with offtake agreements and company debt (Armitage, 2014; Greve, 2015; Riseborough, 2014).

\section{Status of Mineral Development Projects}

Mineral development projects were the underpinnings for the World Bank's forecasts of GDP increases in Guinea, Liberia, and Sierra Leone through 2017. In 2012, it was estimated that for Guinea the development of these projects had the potential to double the country's real GDP by 2015 and to greatly enhance the prospects for future GDP growth through 2017 (World Bank, 2012, p. 2-3). 
Table 2. Mining operations in Guinea, Liberia, and Sierra Leone and their reported operating status in 2014.

[Location and distance information is based on publicly available information and may be approximate for some sites. Abbreviation used: km, kilometer]

\begin{tabular}{|c|c|c|c|c|c|c|c|}
\hline $\begin{array}{l}\text { Label in } \\
\text { figure } 1\end{array}$ & Country & $\begin{array}{l}\text { Mineral } \\
\text { commodity }\end{array}$ & Mine or mineral facility & Location & \multicolumn{2}{|c|}{$\begin{array}{c}\text { Major operating companies and major } \\
\text { equity owners }\end{array}$} & Operating status in 2014 \\
\hline 1 & Guinea & Alumina & Friguia alumina refinery & Fria & \multicolumn{2}{|c|}{$\begin{array}{l}\text { Alumina Company of Guinea (United } \\
\text { Company RUSAL plc, } 100 \% \text { ) }\end{array}$} & $\begin{array}{l}\text { Shut down in April } 2012 . \\
\quad \text { Remained closed in } 2014 .{ }^{1}\end{array}$ \\
\hline 2 & Guinea & Bauxite & Friguia bauxite mine & Fria & \multicolumn{2}{|c|}{$\begin{array}{l}\text { Alumina Company of Guinea (United } \\
\text { Company RUSAL plc, } 100 \% \text { ) }\end{array}$} & $\begin{array}{l}\text { Shut down in April } 2012 . \\
\text { Remained closed in } 2014 .{ }^{1}\end{array}$ \\
\hline 3 & Guinea & Bauxite & Debele (Kindia) Mine & Kamsar & \multicolumn{2}{|c|}{$\begin{array}{l}\text { Compagnie des Bauxites de Kindia (United } \\
\text { Company RUSAL plc, } 100 \% \text { ) }\end{array}$} & $\begin{array}{l}\text { Active as of } \\
\text { December 31, 2014. }{ }^{1}\end{array}$ \\
\hline 4 & Guinea & Bauxite & Sangaredi Mine & $\begin{array}{l}175 \mathrm{~km} \text { north } \\
\text { of Conakry }\end{array}$ & \multicolumn{2}{|c|}{$\begin{array}{l}\text { Compagnie des Bauxites de Guinée } \\
\text { [Halco Mining Inc. (Alcoa Inc., 45\%; } \\
\text { Rio Tinto Alcan Inc., 45\%; Dadco } \\
\text { Group, } 10 \% \text { ), } 51 \% \text {; Government of } \\
\text { Guinea, } 49 \% \text { ] }\end{array}$} & $\begin{array}{l}\text { Active as of } \\
\quad \text { November } 28,2014 .^{2}\end{array}$ \\
\hline 5 & Guinea & Cement & Grinding plant & $\begin{array}{l}35 \mathrm{~km} \text { from } \\
\text { Conakry }\end{array}$ & \multicolumn{2}{|c|}{$\begin{array}{c}\text { Ciments de Guinée, S.A. (Holcim Ltd., } \\
60 \% \text {; Government of Guinea, } 40 \% \text { ) }\end{array}$} & Active as of October 9, $2014 .^{3}$ \\
\hline 6 & Guinea & Gold & Kiniero Mine & $\begin{array}{l}650 \text { km east of } \\
\text { Conakry }\end{array}$ & \multicolumn{2}{|c|}{$\begin{array}{l}\text { New Dawn Mining Corp., } 85 \% \\
\text { (Formerly owned by SEMAFO Inc.; } \\
\text { Kiniero Mine was sold to New Dawn } \\
\text { on May } 28,2014 \text { ) }\end{array}$} & $\begin{array}{l}\text { Active as of } \\
\text { September 30, 2014.4.5 } \\
\text { Status unknown as } \\
\text { of yearend } 2014 .\end{array}$ \\
\hline 7 & Guinea & Gold & Lefa Mine & $\begin{array}{l}700 \text { km northeast } \\
\text { of Conakry }\end{array}$ & \multicolumn{2}{|l|}{ Nord Gold N.V. } & $\begin{array}{l}\text { Active as of } \\
\quad \text { November 20,2014. }{ }^{6}\end{array}$ \\
\hline 8 & Guinea & Gold & Siguiri Mine & $\begin{array}{l}850 \mathrm{~km} \text { northeast } \\
\text { of Conakry }\end{array}$ & \multicolumn{2}{|c|}{ AngloGold Ashanti Limited } & $\begin{array}{l}\text { Active as of } \\
\quad \text { September } 30,2014 .^{7}\end{array}$ \\
\hline 9 & Guinea & Iron ore & Forécariah Mine & $\begin{array}{l}100 \mathrm{~km} \text { east of } \\
\text { Conakry }\end{array}$ & \multicolumn{2}{|c|}{$\begin{array}{l}\text { Forécariah Guinea Mining S.A. (Bellzone } \\
\text { Mining plc, 50\%; China International } \\
\text { Fund Ltd., 50\%) }\end{array}$} & $\begin{array}{l}\text { Active as of June } 2014 . \\
\text { Status unknown as of } \\
\text { yearend } 2014 .^{8,9}\end{array}$ \\
\hline 10 & Liberia & Cement & Cemenco cement plant & Monrovia & \multicolumn{2}{|c|}{$\begin{array}{l}\text { Liberia Cement Corp. Ltd. (Heidelberg } \\
\text { Cement AG) }\end{array}$} & $\begin{array}{l}\text { Active as of } \\
\quad \text { November 6, 2014. }{ }^{10}\end{array}$ \\
\hline 11 & Liberia & Iron ore & Bong Mine & $\begin{array}{l}\text { Bong County, } \\
\text { western Liberia }\end{array}$ & \multicolumn{2}{|c|}{$\begin{array}{l}\text { China Union Investment Co. [Wuhan Iron } \\
\text { and Steel (Group) Corporation] }\end{array}$} & $\begin{array}{l}\text { Active as of } \\
\quad \text { October } 29,2014 .{ }^{11}\end{array}$ \\
\hline 12 & Liberia & Iron ore & Western Range Project & $\begin{array}{c}300 \mathrm{~km} \text { northeast } \\
\text { of Monrovia }\end{array}$ & \multicolumn{2}{|l|}{ ArcelorMittal } & $\begin{array}{l}\text { Active as of yearend } \\
2014 .{ }^{12,13,14,15}\end{array}$ \\
\hline 13 & $\begin{array}{l}\text { Sierra } \\
\text { Leone }\end{array}$ & Bauxite & Sierra Minerals Mine & $\begin{array}{l}150 \mathrm{~km} \text { southeast } \\
\text { of Freetown }\end{array}$ & \multicolumn{2}{|c|}{$\begin{array}{l}\text { Sierra Mineral Holdings } 1 \text { Ltd. } \\
\quad(\text { Vimetco N.V., 100\%) }\end{array}$} & Active as of June $30,2014 .{ }^{16}$ \\
\hline 14 & $\begin{array}{l}\text { Sierra } \\
\text { Leone }\end{array}$ & Cement & Leocem cement plant & Freetown & \multicolumn{2}{|c|}{$\begin{array}{l}\text { Sierra Leone Cement Corp. Ltd. } \\
\text { (HeidelbergCement AG) }\end{array}$} & $\begin{array}{l}\text { Active as of } \\
\quad \text { November 6, 2014. }{ }^{10}\end{array}$ \\
\hline 15 & $\begin{array}{l}\text { Sierra } \\
\text { Leone }\end{array}$ & Diamond & Koidu Kimberlite Mine & $\begin{array}{l}360 \mathrm{~km} \text { east of } \\
\text { Freetown }\end{array}$ & \multicolumn{2}{|c|}{$\begin{array}{l}\text { Octéa Diamond Group (BSG Resources } \\
\text { Ltd., 100\%) }\end{array}$} & $\begin{array}{l}\text { Active as of } \\
\text { December } 12,2014 \cdot{ }^{17,18}\end{array}$ \\
\hline 16 & $\begin{array}{l}\text { Sierra } \\
\text { Leone }\end{array}$ & Iron ore & Marampa Mine & $\begin{array}{l}150 \mathrm{~km} \text { northeast } \\
\text { of Freetown }\end{array}$ & \multicolumn{2}{|c|}{$\begin{array}{l}\text { Timis Corporation Ltd. (Marampa Mine } \\
\text { was formerly owned by London Mining } \\
\text { plc and was acquired by Timis Corp. in } \\
\text { October 2014) }\end{array}$} & $\begin{array}{l}\text { Temporary shutdown (placed } \\
\text { on care-and-maintenance } \\
\text { status). } .^{19,20,21}\end{array}$ \\
\hline 17 & $\begin{array}{l}\text { Sierra } \\
\text { Leone }\end{array}$ & Iron ore & Tonkolili Mine & $\begin{array}{l}190 \mathrm{~km} \text { northeast } \\
\text { of Freetown }\end{array}$ & \multicolumn{2}{|c|}{$\begin{array}{l}\text { Tonkolili Iron Ore (Sierra Leone) Ltd. } \\
\text { (African Minerals Ltd., 75\%; Shandong } \\
\text { Iron and Steel Group Co. Ltd., 25\%) }\end{array}$} & $\begin{array}{l}\text { Temporary shutdown } \\
\text { (placed on care-and- } \\
\text { maintenance status as of } \\
\text { December } 1,2014) .{ }^{22}\end{array}$ \\
\hline 18 & $\begin{array}{l}\text { Sierra } \\
\text { Leone }\end{array}$ & $\begin{array}{l}\text { Mineral } \\
\text { sands } \\
\text { (ilmenite, } \\
\text { rutile, } \\
\text { zircon) }\end{array}$ & Sierra Rutile Mine & $\begin{array}{l}130 \mathrm{~km} \text { southeast } \\
\text { of Freetown }\end{array}$ & Sierra Rutile Ltc & & Active as of yearend..$^{23}$ \\
\hline \multicolumn{3}{|c|}{$\begin{array}{l}{ }^{1} \text { United Company RUSAL plc, 2015a. } \\
{ }^{2} \text { Rio Tinto plc, 2014a. } \\
{ }^{3} \text { de Beaupuy, } 2014 . \\
{ }^{4} \text { New Dawn Mining Corp., 2014. No } \\
\text { ports on the status of the Kiniero Mine } \\
\text { ere publicly available as of yearend } 2014 .\end{array}$} & $\begin{array}{l}{ }^{5} \text { SEMAFO Inc., } 2014 . \\
{ }^{6} \text { Nord Gold N.V., } 2014 . \\
{ }^{7} \text { AngloGold Ashanti Ltd., } 2014 . \\
{ }^{8} \text { Bellzone Mining plc, 2014a. } \\
{ }^{9} \text { Bellzone Mining plc, 2014b. }\end{array}$ & \multicolumn{2}{|c|}{$\begin{array}{l}{ }^{10} \text { HeidelbergCement AG, 2014a. } \\
\text { Corp., } 2014 . \\
\text { Cuhan Iron and Steel (Group) } \\
{ }^{12} \text { ArcelorMittal, 2014b. } \\
{ }^{13} \text { ArcelorMittal, 2014a. }\end{array}$} & $\begin{array}{l}{ }^{14} \text { ArcelorMittal, 2014d. } \\
{ }^{15} \text { ArcelorMittal, 2014c. } \\
{ }^{16} \text { Vimetco N.V., } 2014 . \\
{ }^{17} \text { Green, 2014. } \\
{ }^{18} \text { Biesheuvel, } 2014 .\end{array}$ & $\begin{array}{l}{ }^{19} \text { Riseborough, } 2014 . \\
{ }^{20} \text { Wilson, } 2014 . \\
{ }^{21} \text { Armitage, } 2014 . \\
{ }^{22} \text { African Minerals Ltd., } 2014 . \\
{ }^{23} \text { Sierra Rutile Ltd., } 2015 .\end{array}$ \\
\hline
\end{tabular}


Figure 4 shows the total number of EVD cases as of yearend 2014 and the geographic location of mineral development and exploration projects.

Liberia and Sierra Leone began to show significant signs of economic recovery in the mineral sector with the ramping up of existing mining operations and the resumption of iron ore mining in Liberia in 2010 and in Sierra Leone in 2011. The large number of companies prospecting and exploring for minerals, together with the increasing number of bauxite, diamond, gold, and, in particular, iron ore projects at an advanced stage of development, signaled prospects for continued growth. Many of those mineral projects had significant capital investments committed; total capital investments committed for the development of bauxite and alumina projects in Guinea alone were estimated to be in excess of $\$ 17$ billion (Bates, 2012; Guinea Alumina Corp., 2014; Helmer, 2011; Lyall, 2015; Minesite, 2014; Torchia, 2014). Investments in associated infrastructure projects represented a significant portion of the cost.
Capital expenditures committed for the development of iron ore resources in Guinea were estimated to be in excess of $\$ 10$ billion (Bellzone Mining plc, 2013; BSG Resources Ltd., 2014; Rio Tinto SIMFER S.A., 2014; Sable Mining Africa, Ltd., 2015), a significant amount for a country whose GDP based on purchasing power parity (PPP) was estimated to be about $\$ 14$ billion in 2012. In Liberia, the Putu Range iron ore project alone had committed capital expenditures of $\$ 3$ to $\$ 4$ billion (PAO Severstal, 2012). Liberia's GDP based on PPP in 2012 was estimated to be about $\$ 3$ billion. Committed capital expenditures in advanced development projects in Sierra Leone were about $\$ 200$ million; the country's GDP based on PPP was estimated to be about $\$ 10$ billion in 2012 (Amara Mining plc, 2013; Stellar Diamonds plc, 2010, 2014).

\section{Conclusions}

Mineral production at the industrial scale was to a large extent maintained during 2014 (exceptions are noted in table 2). The activities of mining companies with projects under development or at an early exploration stage, with several exceptions, also continued mostly uninterrupted throughout the year. Quick, coordinated actions on the part of mining companies operating in all three countries helped surrounding communities and national health organizations in their effort to contain the virus. These efforts included (1) securing the perimeter of mining operations, (2) providing training to staff to ensure safety in and around mining facilities and adjacent communities, and (3) establishing health screening and preventative operating protocols to avoid the spread of the EVD. A group of mining companies created an advocacy group to coordinate efforts to address the EVD outbreak and, encouraged by the United Nations, pledged to continue to operate their businesses, to honor financial commitments, and to pay and train staff (ArcelorMittal, 2014b,c; United Nations Global Compact, 2015). Many mining companies also donated funds and medical equipment and

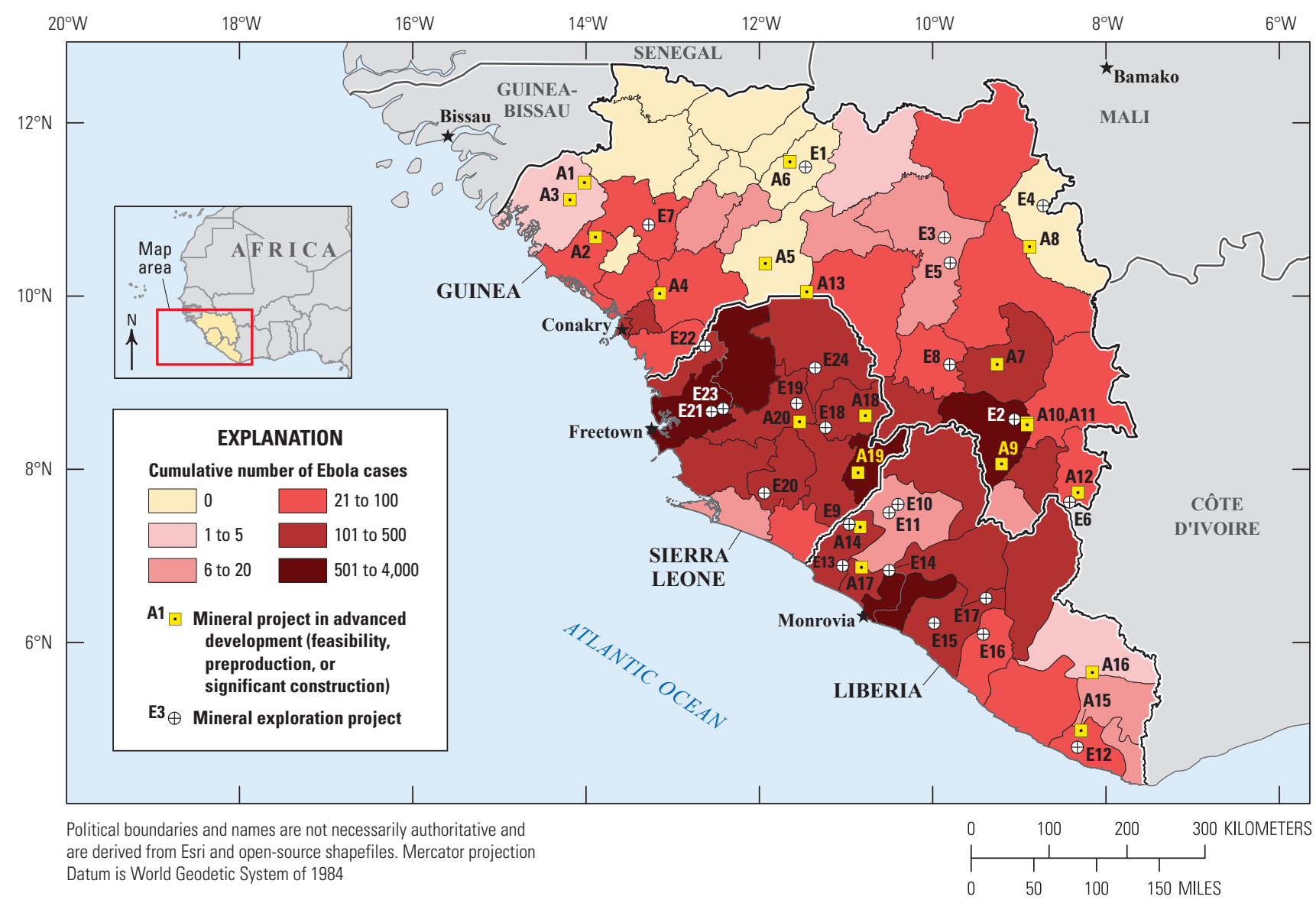

Figure 4. Mineral development and exploration projects in Guinea, Liberia, and Sierra Leone as of yearend 2014. Mineral project locations from Omayra Bermúdez-Lugo (U.S. Geological Survey, unpub. data). 
supplies, among other essential items, to local governments and international organizations (United Company RUSAL plc, 2015b). The transportation of mineral goods to export points also functioned to a significant extent, although the outbreak caused delays in sea freight deliveries at some ports (Sierra Rutile Ltd., 2015). Some commercial flights to and from Guinea, Liberia, and Sierra Leone were cancelled and the limited availability of flights affected business travel for mining companies (Air France, 2014; British Airways, 2014; Emirates, 2014; International Civil Aviation Organization, 2014).

Uncertainty remains as to when, if at all, the Marampa and Tonkolili Mines will resume operation and whether individual iron ore development projects will proceed to production. The prospects for economic growth in Guinea, Liberia, and Sierra Leone hinge on the short-term development of these and other projects. The cancellation or significant delay of these projects would be a major setback for Guinea, Liberia, and Sierra Leone.

\section{References Cited}

African Minerals Ltd., 2014, Financing and operations update: African Minerals Ltd. press release, December 1, 2014, accessed January 8, 2015, at http://www.african-minerals.com/media/ press-releases/financing-and-operations-update.

Air France, 2014, Temporary suspension of Paris-Freetown flights: Air France, August 27, 2014, accessed December 21, 2014, at http://corporate.airfrance.com/en/press/news/article/item/suspension-provisoire-de-la-ligne-paris-freetown-paris-le-27-aout-2014/.

Amara Mining plc, 2013, Baomahun feasibility study confirms robust financial returns: Amara Mining plc, July 2, 2013, accessed December 5, 2014, at http:/www.amaramining.com/ site/CLUF/Templates/General.aspx?pageid=128\&cc=GB.

AngloGold Ashanti Ltd., 2014, Report for the quarter and nine months ended September 30, 2014: AngloGold Ashanti Ltd., p. 7, accessed December 5, 2014, at http://www.anglogoldashanti.com/ en/Media/Pages/reports.aspx.

ArcelorMittal, 2014a, 3Q 2014 Web Q\& A: ArcelorMittal, November 7, 2014, p. 6, accessed January 5, 2015, at http://corporate.arcelormittal.com/ /media/Files/A/ArcelorMittal/ investors/results/previous-results/3Q-2014-Web-QA.pdf.

ArcelorMittal, 2014b, ArcelorMittal statement on operations in Liberia: ArcelorMittal press release, August 8, 2014, accessed January 5, 2015, at http://corporate.arcelormittal.com/newsand-media/press-releases/2014/aug/08-08-2014?lang=english.

ArcelorMittal, 2014c, Ebola private sector mobilisation group established to respond to Ebola crisis: ArcelorMittal press release, November 25, 2014, accessed January 5, 2015, at http://corporate. arcelormittal.com/news-and-media/news/2014/nov/25-11-2014.

ArcelorMittal, 2014d, Strategic progress focused on value drivers: ArcelorMittal presentation at Macquarie Global Metals \& Mining Conference, December 3, 2014, p. 45-46, accessed January 5, 2015, at http://corporate.arcelormittal.com/investors/presentations/2014.

Armitage, Jim, 2014, Concerns rise over Ebola mine deal for tycoon Timis: The Independent [United Kingdom], November 4, 2014, accessed January 2, 2015, at http://www.independent.co.uk/news/ business/news/concerns-rise-over-ebola-mine-deal-for-tycoontimis-9837344.html.

Bank of Sierra Leone, 2014, Annual report and statement of accounts 2013: Bank of Sierra Leone, 145 p., accessed January 1, 2015, at http://www.bsl.gov.sl/articles_publications.html.
Bank of Sierra Leone, 2015, Statistics: Bank of Sierra Leone, accessed January 1, 2015, at http://www.bsl.gov.sl/statistics.html.

Bates, Felix, 2012, Guinea clears China Power Investment \$6 bln alumina project: Thomson Reuters, December 21, 2012, accessed January 2, 2015, at http://www.reuters.com/article/2012/12/21/ guinea-refinery-cpi-idUSL1E8NLB9I20121221.

Bedinger, G.M., 2014, Titanium, in Metals and minerals: U.S. Geological Survey Minerals Yearbook 2012, v. I, September 2014, p. 78.1-78.14. [Also available at http://minerals.usgs.gov/minerals/ pubs/commodity/titanium/myb1-2012-titan.pdf.]

Bellzone Mining plc, 2013, Positive BFS supported by 124.2Mt high grade oxide mineral resources with first production planned in H2 2015: Bellzone Mining plc, September 17, 2013, 4 p., accessed February 1, 2015, at http://www.bellzone.com/images/ downloads/bzm-bfs-kalia-17Sep13.pdf.

Bellzone Mining plc, 2014a, Annual report 2013: Bellzone Mining plc, p. 4, accessed February 4, 2015, at http://www.bellzone.com/ images/downloads/annual_report_final.pdf.

Bellzone Mining plc, 2014b, Forecariah joint venture update: Bellzone Mining plc press release, June 20, 2014, 2 p., accessed February 4, 2015, at http://www.bellzone.com/images/downloads/ bellzone-fjv-update-20june2014.pdf.

Bermúdez-Lugo, Omayra, 2014a, The mineral industry of Guinea, in Area reports - International-Africa and the Middle East: U.S. Geological Survey Minerals Yearbook 2012, December 2014, v. III, p. 21.1-21.4. [Also available at http://minerals.usgs.gov/ minerals/pubs/country/2012/myb3-2012-gv.pdf.]

Bermúdez-Lugo, Omayra, 2014b, The mineral industry of Liberia, in Area reports - International-Africa and the Middle East: U.S. Geological Survey Minerals Yearbook 2013, December 2014, v. III, p. 21.1-21.4. [Also available at http://minerals.usgs.gov/ minerals/pubs/country/2013/myb3-2013-li.pdf.]

Bermúdez-Lugo, Omayra, 2014c, The mineral industry of Sierra Leone, in Area reports-International-Africa and the Middle East: U.S. Geological Survey Minerals Yearbook 2012, December 2014, v. III, p. 21.1-21.4. [Also available at http://minerals.usgs.gov/minerals/pubs/country/2012/myb3-2012-sl.pdf.]

Biesheuvel, Thomas, and Kitamura, Makiko, 2014, Ebola's spread in Sierra Leone puts diamond mines at risk: Bloomberg L.P., December 11, 2014, accessed January 1, 2015, at http://www. bloomberg.com/news/2014-12-11/ebola-s-spread-in-sierra-leoneputs-diamond-mines-at-risk.html.

British Airways, 2014, Flights to/from Liberia and Sierra Leone suspended: British Airways, December 15, 2014, accessed December 21, 2014, at http://www.britishairways.com/travel/ gsanswer/public/en_us?faqid=5072\&gsLink=searchResults.

BSG Resources Ltd., 2014, Iron ore-BSGR Guinea history: BSG Resources Ltd., accessed February 1, 2015, at http://www.bsgresources.com/mining-and-metals/iron-ore/.

Centers for Disease Control and Prevention, 2015a, 2014 Ebola outbreak in West Africa-Case counts: Centers for Disease Control and Prevention, January 20, 2015, accessed January 25, 2015, at http://www.cdc.gov/vhf/ebola/outbreaks/2014-west-africa/ case-counts.html.

Centers for Disease Control and Prevention, 2015b, 2014 Ebola outbreak in West Africa-Cumulative reported cases graphs: Centers for Disease Control and Prevention, January 20, 2015, accessed January 25, 2015, at http://www.cdc.gov/vhf/ebola/ outbreaks/2014-west-africa/cumulative-cases-graphs.html. 
Central Bank of Liberia, 2014, Central Bank of Liberia annual report 2013: Monrovia, Liberia, Central Bank of Liberia, January 22, 2014, 65 p., accessed January 1, 2015, at http://www. cbl.org.lr/doc/annualreports/cblannualreport2013.pdf.

Central Bank of Liberia, 2015, Central Bank of Liberia annual reports, accessed January 1, 2015, at http://www.cbl.org.lr/ annual_reports.php?sub=annuals.

de Beaupuy, Francois, 2014, Lafarge sees bids for all units on sale in Holcim merger: Bloomberg, October 9, 2014, accessed December 5, 2014, at http://www.bloomberg.com/news/2014-1009/lafarge-sees-bids-for-all-units-on-sale-in-holcim-merger.html.

Emirates, 2014, Operational update: Emirates, August 2, 2014, accessed, January 14, 2015, at http://www.emirates.com/us/ english/about/operational_updates/operational_updates.aspx.

Gleeson, Daniel, 2014, Analysts question major dimensions: Mining Journal, March 28, 2014, p. 1, 7.

Green, Regie, 2014, Sierra Leone's mining industry is now suffering because of Ebola: Bio \& Tech Insights, December 12, 2014, accessed December 21, 2014, at http://biotechinsights.com/ sierra-leones-mining-industry-is-now-suffering-because-ofebola/14397/.

Greve, Natalie, 2015, Ebola not to blame for failure of African mining companies: Mining Weekly, January 13, 2015, accessed February 3, 2015, at http://www.miningweekly.com/article/ ebola-not-to-blame-for-failure-of-african-mining-companiesadvisory-2015-01-13.

Guinea Alumina Corp., 2014, About Guinea Alumina Corporation: Guinea Alumina Corp., video, 7:10 min, accessed January, 2, 2015, at http://www.guineaalumina.com/.

[Guinea] Institut National de la Statistique, 2014, Annuaires statistiques: Institut National de la Statistique, accessed December 19, 2014, at http://www.stat-guinee.org/index.php/ documents-publies/annuaire-stat.

HeidelbergCement AG, 2014, Interim financial reportJanuary to September 2014: Heidelberg Cement AG, p. 9, accessed December 5, 2014, at http://www.heidelbergcement. com/en/financial-reports-and-presentations.

Helmer, John, 2011, Guinea rejects Rusal proposal to dig DianDian slowly, keep bauxite in the ground: Business Insider, June 30, 2011, accessed March 9, 2015, at https://web.archive. org/web/20110701164008/http://www.businessinsider.com/handjob-8212-guinea-rejects-rusal-proposal-to-dig-dian-dian-slowlykeep-bauxite-in-the-ground-2011-6.

International Civil Aviation Organization, 2014, Joint statement on Ebola virus disease (EVD) outbreak: International Civil Aviation Organization press release, August 18, 2014, accessed December 21, 2014, at http://www.icao.int/Newsroom/Pages/ joint-statement-on-Ebola-virus-disease-outbreak.aspx.

International Monetary Fund, 2014, Guinea and the IMF: International Monetary Fund Web site, accessed December 19, 2014, at http://www.imf.org/external/country/GIN/index.htm.

Kimberley Process Rough Diamond Statistics, 2013, Annual global summary-2012 production, imports, exports and KPC counts: Kimberley Process Rough Diamond Statistics, June 19, 2013, accessed December 1, 2014, at https://kimberleyprocessstatistics. org/static/pdfs/public_statistics/2012/2012GlobalSummary.pdf.
Lyall, Ian, 2015, Anglo-African looks to the near-term with its FAR bauxite deposit: Anglo-African Minerals press release, January 19, 2015, accessed February 1, 2015, at http://www. angloafricanmineralsplc.com/media/news/.

Minesite, 2014, Anglo-African Minerals aims to generate US\$20 million a year selling bauxite from the FAR Project in Guinea: Minesite, July 23, 2014, accessed December 4, 2014, at http://minesite.com/2014/07/23/anglo-african-minerals-aimsto-generate-us20-million-a-year-selling-bauxite-from-the-farproject-in-guinea/.

New Dawn Mining Corp., 2014, New Dawn provides final report on recent corporate actions: New Dawn Mining Corp., January 21, 2014, accessed February 3, 2015, at http://www. newdawnmining.com/new-dawn-provides-final-report-on-recentcorporate-actions.

Nord Gold N.V., 2014, Nord Gold N.V. reports financial and operating results for the third quarter and nine months ended September 30, 2014: Nord Gold N.V., November 20, 2014, p. 15, accessed January 3, 2015, at http://www.nordgold.com/investorsand-media/results-and-reports/.

PAO Severstal, 2012, Severstal greenfield day: PAO Severstal business presentation, November 23, 2012, p. 28-31, accessed December 5, 2014, at http:/www.severstal.com/eng/ir/conferences_presentations/business_presentations/index.phtml.

Pushak, Nataliya, and Foster, Vivien, 2011, Sierra Leone's infrastructure; A continental perspective: World Bank Policy Research Working Paper WPS5713, accessed December 12, 2014, at http://documents.worldbank.org/curated/en/2011/06/14482920/ sierra-leones-infrastructure-continental-perspective.

Rio Tinto plc, 2014a, Rio Tinto investor seminar, Sydney-Q\&A transcript: Rio Tinto plc, November 28, 2014, p. 7, accessed January 11, 2015, at http://www.riotinto.com/documents/Rio Tinto_Investor_Seminar_Q_and_A transcript.pdf.

Rio Tinto SIMFER S.A., 2014b, Simandou economic impact report-Investment framework update: Rio Tinto SIMFER S.A. report, September, 2014, p. 1-10, accessed January 11, 2015, at http://www.riotinto.com/documents/RT_Simandou_Economic Impact_Report_EN.pdf.

Riseborough, Jesse, 2014, African iron ore producer facing 'end of the road': Bloomberg L.P., November 21, 2014, accessed January 13, 2015, at http://www.bloomberg.com/news/2014-11-21/ african-iron-ore-producer-facing-end-of-the-road-.html.

Sable Mining Africa, Ltd., 2015, Nimba development: Sable Mining Africa Ltd., accessed March 19, 2015, http://www.sablemining. com/portfolio/nimba-development.html.

SEMAFO Inc., 2014, Management's discussion and analysis: SEMAFO Inc., September 30, 2014, p. 24, accessed December 8, 2014, at http:/www.semafo.com/financialreports.php? $\mathrm{y}=2014$.

Sierra Rutile Ltd., 2015, Sierra Rutile provides Q4 2014 operational update and 2015 guidance: Sierra Rutile Ltd., January 12, 2015, accessed January 13, 2015, at http://www.sierra-rutile.com/ uploads/q42014tradingupdate.pdf.

Stellar Diamonds plc, 2010, Acquisition of Kono diamond project, Sierra Leone: Stellar Diamonds plc press release, May 4, 2010, accessed January 16, 2015, at http://stellar-diamonds.com/news/ press/acquisition-of-kono-diamond-project-sierra-leone. 
Stellar Diamonds plc, 2014, Positive study for acceleration of cash flows from surface mining at Tongo Project in Sierra Leone: Stellar Diamonds plc press release, December 3, 2014, accessed January 16, 2015, at http://stellar-diamonds.com/news/press/ positive-study-for-acceleration-of-cash-flows-from-surfacemining-at-tongo-project-in-sierra-leone.

Torchia, Andrew, 2014, UAE to build $\$ 3$ bln alumina refinery by end-2017: Thomson Reuters, September 23, 2014, accessed December 4, 2015, at http://af.reuters.com/article/metalsNews/ idAFL6N0RO0XZ20140923.

Tuck, C.A., 2014, Iron ore, in Metals and minerals: U.S. Geological Survey Minerals Yearbook 2012, v. I, September 2014 , p. 39.1-39.18. [Also available at http://minerals.usgs.gov/ minerals/pubs/commodity/iron_ore/myb1-2012-feore.pdf.]

United Company RUSAL plc, 2015a, UC RUSAL announces fourth quarter and full year 2014 operating results: United Company RUSAL plc press release, January 30, 2015, accessed March 20, 2015, at http://www.rusal.ru/en/press-center/pressreleases.aspx.

United Company RUSAL plc, 2015b, UC RUSAL opens a modern epidemiology centre in Guinea: United Company RUSAL plc press release, January 19, 2015, accessed February 2, 2015, at http://www.rusal.ru/en/press-center/news details.aspx?id=11602\&ibt=13.

United Nations Global Compact, 2015, CEO action pledge on Ebola eradication: United Nations Global Compact, accessed February 1, 2015, at https://business.un.org/en/documents/ business_action_pledge_signatories.

United Nations Security Council, 2007, Letter dated 7 June 2007 from the Chairman of the Security Council Committee established pursuant to resolution 1521 (2003) concerning Liberia addressed to the President of the Security Council: Washington, DC, United Nations Security Council, June 7, 50 p.

van Oss, H.G., 2015, Cement, in Metals and minerals: U.S. Geological Survey Minerals Yearbook 2012, v. I, March 2015, p. 16.1-16.32. [Also available at http://minerals.usgs.gov/ minerals/pubs/commodity/cement/myb1-2012-cemen.pdf.]

Vimetco N.V., 2014, Half-year report 2014: Vimetco N.V., accessed December 12, 2014, at http://www.vimetco.com/ir/reports.

Wilson, James, 2014, London Mining on brink of collapse as shares plunge: The Financial Times, [London, United Kingdom] October 8, 2014, accessed December 1, 2014, at http:/www.ft.com/cms/s/0/7956e508-4ebd-11e4-a1ef00144feab7de.html\#axzz3WFqFs4MU.

World Bank, 2012, International development association project appraisal document proposed grant in the amount of SDR 13.3 million (\$20 million equivalent) to the Republic of Guinea for a mineral governance support project, August 21, 2012: World Bank International Development Association Project Appraisal Document 72245-GN, 62 p., accessed January 12, 2015, at http://www-wds.worldbank.org/ external/default/WDSContentServer/WDSP/IB/2012/09/10/ 000386194_20120910010000/Rendered/PDF/722450PAD0P 1220Official0Use0Only090.pdf.

ISSN 2327-6916 (print) ISSN 2327-6932 (online) http://dx.doi.org/10.3133/fs20153033
World Bank, 2013, Implementation completion and results report on a grant in the amount of US\$8.5 million to the Republic of Liberia for an infrastructure rehabilitation project, February 25, 2013: World Bank Implementation and Completion Results Report ICR1708, 44 p., accessed January 12, 2015, at http://www-wds. worldbank.org/external/default/WDSContentServer/WDSP/ IB/2013/04/02/000442464 20130402104326/Rendered/PDF/ ICR17080P101450IC0disclosed04010130.pdf.

World Bank, 2014, Guinea-WB [World Bank] supports improved electricity access and reliability for families and businesses: World Bank press release, July 3, 2014, accessed January 12, 2015, at http://www.worldbank.org/en/news/pressrelease/2014/07/03/guinea-wb-supports-improved-electricityaccess-and-reliability-for-families-and-businesses.

World Bank Group, 2014, Update on the economic impact of the 2014 Ebola epidemic on Liberia, Sierra Leone, and Guinea: World Bank Group, December 2, 2014, accessed January 12, 2015, at http://documents.worldbank.org/curated/ en/2014/12/20454884/update-economic-impact-2014-ebolaepidemic-liberia-sierra-leone-guinea.

World Health Organization, 2014, Ebola virus disease: World Health Organization Fact Sheet 103, accessed January 15, 2015, at http://www.who.int/mediacentre/factsheets/fs103/en/.

World Health Organization, 2015, Ebola situation report-31 December 2014: World Health Organization, 16 p., accessed January 15, 2015, at http://apps.who.int/ebola/en/ status-outbreak/situation-reports/ebola-situation-report-31december-2014.

Wuhan Iron and Steel (Group) Corp., 2014, China's Ambassador to Liberia visited the staff of WISCO Bong Mines Company in Liberia: Wuhan Iron and Steel (Group) Corp., October 13, 2014, accessed December 1, 2014, at http://english.wisco.com.cn/ News/1036.jhtml.

\section{By Omayra Bermúdez-Lugo and W. David Menzie}

The USGS National Minerals Information Center (NMIC) collects, analyzes, and disseminates information on the international supply of and demand for minerals and mineral materials essential to the U.S. and world economies for more than 170 mineral producing countries around the world. Guinea, Liberia, and Sierra Leone are among the countries for which these types of data are collected and analyzed.

\section{For more information, contact:}

Director, National Minerals Information Center

U.S. Geological Survey

12201 Sunrise Valley Drive

988 National Center

Reston, VA 20192

Email: nmicrecordsmgt@usgs.gov

Or visit the USGS Minerals Information Web site at http://minerals.usgs.gov/minerals/ 